
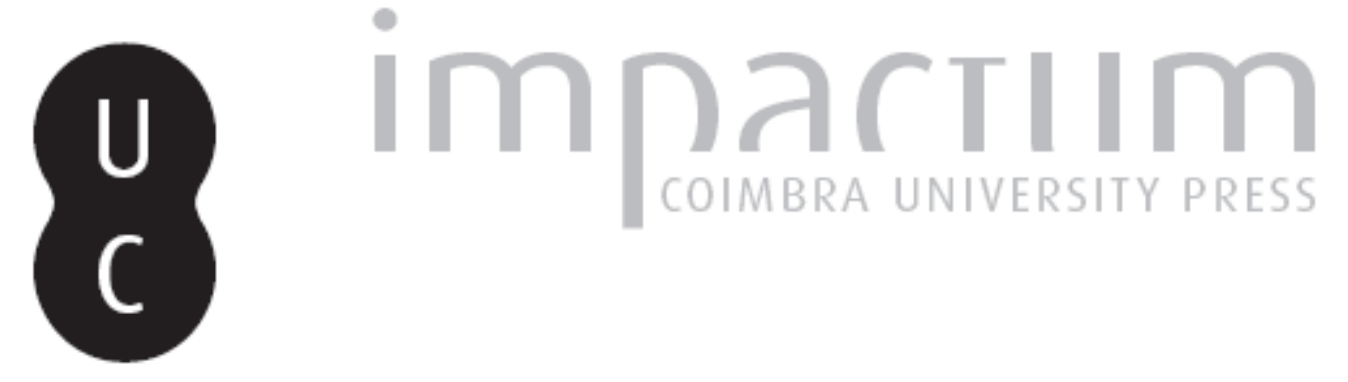

\title{
[Recensão a] Bearzi, M.; Stanford, C. B. 2008 - Beautiful minds: the parallel lives of great apes and dolphins
}
Autor(es):
Carvalho, Susana
Publicado por: CIAS - Centro de Investigação em Antropologia e Saúde
URL persistente:
URI:http://hdl.handle.net/10316.2/28705
DOI:
DOI:http://dx.doi.org/10.14195/2182-7982_27_15
Accessed : $\quad$ 26-Apr-2023 13:18:52

A navegação consulta e descarregamento dos títulos inseridos nas Bibliotecas Digitais UC Digitalis, UC Pombalina e UC Impactum, pressupõem a aceitação plena e sem reservas dos Termos e Condições de Uso destas Bibliotecas Digitais, disponíveis em https://digitalis.uc.pt/pt-pt/termos.

Conforme exposto nos referidos Termos e Condições de Uso, o descarregamento de títulos de acesso restrito requer uma licença válida de autorização devendo o utilizador aceder ao(s) documento(s) a partir de um endereço de IP da instituição detentora da supramencionada licença.

Ao utilizador é apenas permitido o descarregamento para uso pessoal, pelo que o emprego do(s) título(s) descarregado(s) para outro fim, designadamente comercial, carece de autorização do respetivo autor ou editor da obra.

Na medida em que todas as obras da UC Digitalis se encontram protegidas pelo Código do Direito de Autor e Direitos Conexos e demais legislação aplicável, toda a cópia, parcial ou total, deste documento, nos casos em que é legalmente admitida, deverá conter ou fazer-se acompanhar por este aviso.

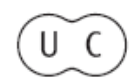




\section{Antropologia Portuguesa}

Volume $26-27 \cdot 2009-2010$

Departamento de Antropologia | Universidade de Coimbra

DARWINISMO:

revisitações, propostas, problemas 


\section{Recensões}

Bearzi, M.; Stanford, C. B. 2008. Beautiful minds: the parallel lives of great apes and dolphins. Cambridge, Massachusetts, Harvard University Press, 351 pp. ISBN 9780674027817 [Hardcover edition]. US\$24,95.

\section{Beautiful minds: so far yet so close...}

Maddalena Bearzi, an experienced cetologist, and Craig Stanford, an authority on great apes, have joined efforts to write a timely book that a large audience has needed for the last decade. The more that great apes and cetaceans are studied, the more similarities seem to emerge, making these remotely related mammals - who shared a last common ancestor about 100 million years ago - an extraordinary example of convergent encephalization of divergent brains. Although it may appear to be a puzzling paradox, this is natural selection working in the standard Darwinian manner. This book neatly explores the principles of how species undergo the process of convergent evolution, and provides one of the most elegant examples of the power of selection in face of ecological diversity. Regrettably, convergence has been conveniently transformed into a dangerous concept, poorly understood and wrongly applied by modern creationists. As Charles Darwin predicted, several of his main principles would be distorted, "[f]or I am well aware that scarcely a single point is discussed in this volume on which facts cannot be adduced, often apparently leading to conclusions directly opposite to those at which I have arrived" (Darwin, 1859: 2). In contrast, the authors of Beautiful minds accurately highlight this evolutionary process by which some organisms in distant phylogenetic lines have evolved near-identical adaptations to different environmental niches that generate similar selective pressures.

The book is labeled as a good promoter of public science, targeting mainly non-scientific audiences, but I suspect that many researchers, both primatologists and cetologists, will, after reading this book, find their knowledge much enhanced about at least one of the focused species. As a primatologist, I discovered much about cetacean behavioral ecology, cognition, and the history of dolphin and whale research. But, I agree that this book provides a particularly good introduction to the subject for undergraduates and the general public that is helped by easy-tounderstand language.

By sharing many of their personal experiences, as a device to illustrate the theoretical arguments, the authors succeed in keeping the reader emotionally involved from the first page to the last. Much of this success comes from the ability of both 
authors to convey how deeply enchanted they remain by their subjects, even after decades of research. Side by side, the book is written in a "mirror" format in which each author alternates the evolutionary story of great apes and cetaceans - while keeping the main focus on chimpanzees and dolphins -, and provides a broad range of perspectives that demonstrate how brain, social and ecological complexity are tied to the emergence of intelligence as an evolutionary adaptation.

The book's eight chapters take the reader through contrasting journeys of aquatic and terrestrial fieldwork memories and relevant scientific discoveries that have contributed to the identification of important common traits among these mammals' societies. The book also highlights the many difficulties encountered by researchers who simultaneously are struggling to overcome the physical demands and constraints of fieldwork and the challenges of attributing cognitively complex processes to any non-human species; this is especially true for cetaceans. During this expedition, the reader discovers remarkable similarities across ape and cetacean societies, with both being characterized by complex, long-term individual relationships. Besides intricate social interactions and fission-fusion societies, in the case of chimpanzee and dolphin, what else do these beautiful minds share? Both have highly flexible and adaptive behavioral repertoires, for example, whereby daily politics are negotiated through versatile alliances and coalitions, parties engage in cooperative hunting and use complicated communication skills, and employ mechanisms of learning and transmission of behavior that include capacities for solving problems, including technological intelligence. At a different level - although no consensus has been reached among scientists -, the authors emphasise the identification of cultural traditions in these species, as well as deceptive and manipulative behavior based on the existence (or not) of a theory of mind in great apes and cetaceans. When comparing cetaceans and primates, the authors give both observational and experimental perspectives, and discuss constraints imposed by captive settings, stating that regardless of methodological rigor, the mentalities of these animals has evolved under unique selective pressures in natural environments, and so laboratories may not allow accurate evaluation of some aspects of their cognition.

However, I disagree with some of the content of the book: many examples that illustrate much of dolphin and whale research are anecdotal or comprised of mythical human perceptions of cetacean intelligence. Although these are interesting inclusions, this historical approach should not set research standards for examining cetacean cognitive ability. Conversely, the reader gets the impression that tool-use among apes is almost entirely anecdotal, which (with regard to chimpanzees) is decades out of date. An equally misleading humanized view of the chimpanzees 
occurs at some points, especially concerning the description of the American Sign Language experiments. By current primatological standards, it is neither normal nor appealing to have raised a chimpanzee to behave like a human. Likewise, incessant use of the demeaning diminutive term chimp is also unfortunate. Finally, when reading about self-awareness and the ability to deceive, the reader may think that these are well-established capacities for both species, but in reality, both are currently highly debatable topics in primate and cetacean research.

In summary, I welcome the idea of dolphins and whales giving us good independent comparation points to better understand the forces that led to brain complexity or encephalization. Because cetaceans evolved convergently, under very different conditions, their parallel lives can give us some important clues about the process of encephalization in humans. An extra chapter focusing on conservation closes this book. I found this unhappy conclusion to be sobering and well-reasoned, essentially because the writing feels genuine, unlike some of the environmentalist discourses. This ending hits the reader hard. We are guided through the issues of a natural world that has been severely damaged, so that species vanish forever. While the first eight chapters of this book will be enjoyed by many readers, the authors' plea to meet our fundamental ethical obligation to conserve the natural world should reach out to all of us.

\title{
Outras referências:
}

Darwin, C. 1859. On the origin of species by means of natural selection, or the preservation of favoured races in the struggle for life. London, John Murray.

\section{Susana Carvalho ${ }^{1,2}$}

\author{
${ }^{1}$ Leverhulme Centre for Human Evolutionary Studies \\ University of Cambridge \\ Cambridge CB2 1QH, UK \\ ${ }^{2}$ CIAS - Centro de Investigação em Antropologia e Saúde \\ Departamento de Ciências da Vida \\ Faculdade de Ciências e Tecnologia \\ Universidade de Coimbra, Portugal \\ scr50@cam.ac.uk
}

